Таким образом, общим признаком способов обеспечения исполнения обязательств является то, что они относятся к мерам, гарантирующим исполнение основного обязательства и стимулирующим должника к надлежащему поведению.

$$
* * *
$$

1. Гражданский кодекс Российской Федерации (часть первая): Федер. закон [принят Гос. Думой 21.11.1994] // Собрание законодательств РФ. 1994. № 32. Ст. 3301.

2. Об ипотеке (залоге недвижимости): Федер. закон [принят Гос. Думой 24.06.1997] // Собр. законодательства Рос. Федерации. 1998. № 29. Ст. 3400 .О некоторых вопросах разрешения споров, связанных с поручительством: постановление Пленума ВАС РФ от 12.07.2012 № 42 // Вестник Высшего Арбитражного Суда РФ. 2012. № 9.

3. Определение Судебной коллегии по гражданским делам Верховного Суда РФ от 18.07.2017 № 5КГ17-94 // Обзор судебной практики Верховного Суда РФ № 4 (2017): информационное письмо Верховного Суда РФ от 15.11.2017. URL: https://demo.garant.ru/\#/document/71736384/paragraph/1:9 (дата обращения: 16.04.2021).

4. Милевская Е.В. Обеспечение исполнения обязательств при заключении сделки / Е.В. Милевская // Divius.ru. 12.05.2017. URL: https://divius.ru/blog/obespechenie-ispolneniya-obyazatelstv-prizaklyuchenii-sdelki/ (дата обращения: 16.04.2021).

5. Шестакова Е.В. Договорное право в практике арбитражных судов / Е.В. Шестакова. М.: "Право Доступа", 2019.2 URL: https://demo.garant.ru/\#/document/77503949/paragraph/648/doclist/17/showentries/0/highlight （дата обращения: 16.04.2021).

\title{
Биджиева А.К. \\ Правовая регламентация института обязательного страхования в российском законодательстве
}

ФГБОУ ВО «Северо-Кавказская государственная я академия»

(Россия, Черкесск)

doi: 10.18411/lj-05-2021-165

\section{Аннотация}

В этой статье анализируются правовые основы построения системы обязательного страхования путем изучения норм современного российского гражданского права. В начале автор ссылается на положения Конституции Российской Федерации провозгласить Российскую Федерацию социальным государством, определив тем самым генезис страхового института. Исследованы основания возникновения правоотношений в поле страхования, нормы, обязывающие граждан и юридические сущности вступать в рассматриваемые правоотношения. Проведена классификация видов обязательного страхования.

Ключевые слова: обязательное страхование, страховая деятельность, договор страхования, страховое право, трехступенчатая система правового регулирования страхования.

\section{Abstract}

This article analyzes the legal basis for building a mandatory insurance system by studying the norms of modern Russian civil law. In the beginning, the author refers to the provisions of the Constitution of the Russian Federation to proclaim the Russian Federation a social state, thereby determining the genesis of the insurance institution. The article examines the grounds for the emergence of legal relations in the field of insurance, the norms that oblige citizens and legal entities to enter into the legal relations under consideration. The classification of types of compulsory insurance is carried out.

Keywords: compulsory insurance, insurance activity, insurance contract, insurance law, three-stage system of legal regulation of insurance. 
В настоящее время трудно представить современное общество без страховки, так как жизнь, здоровье, собственность человека, материальные объекты, с которыми связана деятельность человека, часто зависят от непредвиденных и неизбежных событий, иными словами, предпосылки для страховки уже заложены в самом существовании человека, общества.

Страховое право - отрасль права, изучающая связи с общественностью в сфере страхования. Под страхованием понимаются отношения по защите интересов субъектов гражданского права в случае возникновения определенных страховых случаев за счет денежных средств, сформированных страховщиками (п. 1 ст. 23 РФ от 27.11.1992 № 4015-1).

Общество постоянно вынуждено решать проблему защиты от экономических последствий стихийных бедствий, несчастных случаев на производстве и катастроф, обеспечивая интересы семей и отдельных граждан в случае непредвиденных неблагоприятных последствий. Страхование является важнейшим способом минимизации и устранения таких экономических потерь.

Подчиняясь мировым тенденциям, страхование в России, в том числе обязательное государственное страхование жизни и здоровья, развивается динамично. При этом особая роль страхования проявляется в решении социальных проблем общества.

Все правоотношения, связанные со страхованием, можно разделить на две группы: правоотношения, регулирующие само страхование, то есть процесс формирования и использования страхового фонда, и правоотношения, возникающие при организации страхового случая, то есть деятельность страховщиков, их взаимоотношения с банками, бюджетом, государственными органами.

Оба отношения регулируются законодательными и иными правовыми актами. Принято, что первая группа правоотношений охватывается полем гражданского права, а вторая - государственной, административной, финансовой, уголовно-процессуальной и другими отраслями права и подветвями права.

В Российской Федерации, как и в ряде западных государств (например, в Германии) сложилась трехступенчатая система правового регулирования страхового дела.

Первая ступень-общее гражданское право. К первой ступени правового регулирования страхования следует отнести, прежде всего, Гражданский кодекс (ГК) РФ и другие подобные нормативные акты.

Гражданское право и, соответственно, гражданское право регулируют коммерческие, денежные и иные имущественные и неимущественные отношения, возникающие между субъектами гражданских правоотношений. Субъекты здесь граждане (физические лица), предприятия, организации, учреждения ( юридические сущности) и государственные органы. Объектами гражданско-правовых отношений являются материальные и денежные ценности, а также иные материальные и нематериальные выгоды. Объектами страховых отношений также являются материальные и денежные ценности (имущество, расходы, доходы) и нематериальные личные блага человека - жизнь, здоровье, трудоспособность, то есть риск потери семейного дохода вследствие утраты здоровья или смерти в течение страхового периода. В сущностях находятся страховщики, страховщики и третьи вечеринки. Все это свидетельствует о том, что страховые правоотношения относятся к сфере гражданского права, к разделу обязательного права.

Часть 1 Гражданского кодекса РФ устанавливает понятия, лежащие в основе страховых правоотношений, такие как, например, физическое лицо, юридический объект, коммерческая и некоммерческая деятельность, определяет основные 
организационно-правовые формы предпринимательской деятельности, содержит основы обязательного права.

Часть 2 Гражданского кодекса РФ содержит специальную главу 48 «Страхование», определяющую основы отношений в отношении страхования как отдельного вида экономических отношений.

Вторая ступень - специальное законодательство по страхованию. Сюда входят отдельные законы Российской Федерации, регулирующие страховые отношения. К ним относятся, прежде всего, Закон Российской Федерации «Об организации страхования в Российской Федерации», Закон Российской Федерации «О медицинском страховании граждан в Российской Федерации», Законы «Об обязательном страховании гражданской ответственности владельцев транспортных средств», «О взаимном страховании» и другие федеральные законы.

Закон Российской Федерации «Об организации страхования в Российской Федерации» призван создать равные условия для страхования всех страховщиков на страховом рынке, как государственных, так и негосударственных, гарантировать защиту интересов страховщиков, определить единые методологические положения по организации страхования и основные принципы государственного регулирования страховой деятельности.

Третья ступень - прочие нормативные акты. К ним относятся указы Президента Российской Федерации, резолюций Правительства, подзаконные акты министерств и ведомств. Общие требования законодательства о регулировании отношений в поле страхования заключаются в том, что законодательные акты первого и второго этапов дают основные понятия, связанные со страховыми правоотношениями, содержат общие требования к договорам обязательного и добровольного страхования. Другие нормативные акты содержат требования по отдельным вопросам осуществления страховой деятельности.

Законодательная основа обязательного страхования - часть вторая Гражданского кодекса Российской Федерации (статьи 927. 935 - 937 и 969) и Федерального закона Российской Федерации о 31.12.97. № 157-FZ «Об организации страхового бизнеса в Российской Федерации». Помимо этих основных законодательных актов, особенности обязательного государственного личного страхования различных категорий граждан регулируются другими законами.

В соответствии с пунктом 2 статьи 927 Гражданского кодекса Российской Федерации, обязательное страхование - страхование в случаях, когда указанные в нем лица обязаны по закону страховать в качестве страховщиков жизнь; здоровья или имущества других лиц или их гражданской ответственности перед другими лицами за свой счет или за счет заинтересованных лиц.

Можно выделить следующие особенности: страховая премия определяется законом; страхование осуществляется за счет бюджета; действие обязательного страхования независимо от уплаты страховых выплат; бессрочное обязательное страхование.

Обязательное страхование осуществляется через заключение договора страхования. Исключением из этого правила является государственное обязательное страхование, которое может осуществляться в бездоговорной форме. Застрахованным по договору обязательного страхования является лицо, которое несет ответственность за такое страхование.

Основные принципы основных средств:

- принцип полного покрытия обязательного страхования означает включение в сферу страхования всех объектов, указанных в законе. 
- принципы гласности и конфиденциальности отражают, соответственно, степень открытости и раскрываемости представленной информации, основанной на законодательно установленных договорных отношениях по обязательному страхованию.

- принцип бессрочности обязательного страхования означает его действительность на весь период существования объекта или застрахованного.

- принцип зарядки по минимальной ставке означает установление заранее определенной тарифной ставки для обязательных видов страхования, отражающей минимальный уровень цены страхового риска. Это связано с всеобщим участием, наличием страхового покрытия и механизма затрат в системе обязательного страхования.

— принцип обязательной компенсации применяется только к обязательной форме страхования и отражает цель, сущность и идею самой обязательной страховой системы. Независимо от обстоятельств застрахованного события и других факторов, страховые платежи всегда выплачиваются пострадавшим в течение крайних сроков, установленных законом.

- принцип нормирования страховых платежей в обязательном страховании означает учреждение предопределенных сумм страховой компенсации (безопасность), независимо от суммы повреждения, количества страховых случаев, и т.д.

Гражданский кодекс устанавливает следующие виды страхования, которые могут быть обязательными:

1) страхование жизни, здоровья или имущества лиц, определенных законом, в случае причинения вреда их жизни, здоровью или имуществу.

Примечательно, что в отношении страхования этих предметов (жизни, здоровья, имущества) может быть введено обязательное страхование в отношении третьих вечеринок, но не застрахованных.

Подчеркивая это обстоятельство, Гражданский кодекс устанавливает, что обязанность по страхованию своей жизни или здоровья не может быть возложена на гражданина законом (например, обязательное медицинское страхование, обязательное военное страхование и т.д.);

2) страхование риска гражданской ответственности страхователя, которая может произойти в результате причинения вреда жизни, здоровью или имуществу других лиц или нарушения договоров с другими лицами (например, ОСАГО, страхование ответственности перевозчика, собственников опасных объектов и т.д.);

3) страхование имущества, являющегося государственной или муниципальной собственностью и принадлежащего юридическим лицам на праве хозяйственного или оперативного управления.

Также обязательное страхование можно разделить на государственное и социальное (включает обязательное пенсионное, социальное и медицинское страхование).

Таким образом, в настоящее время институт обязательного страхования занимает ключевое положение в страховой деятельности, является перспективной отраслью страхования, так как позволяет государству ограничить финансовую ответственность за некоторые социально значимые убытки, которые ему в противном случае пришлось бы компенсировать. Однако дальнейшее развитие института 
обязательного страхования должно отвечать современным требованиям российской экономики, правовой системы, а также учитывать интересы населения.

$$
* * *
$$

1. Алексеева Е.В. Современное состояние и проблемы обязательного страхования в России / Е.В.Алексеева // Вестник Оренбургского государственного университета. — 2017. — № 10. — С. 81-87.

2. Боброва А.В. Оптимизация страховых взносов на обязательное страхование / А.В. Боброва, В.С. Климонова // Управление в современных системах. - 2019. - № 1. - С. 17-23.

3. Гражданский кодекс Российской Федерации (часть первая) от 26.01.1996 № 14-ФЗ (ред. от 28.03.2017) / Правовой Сервер КонсультантПлюс [Электронный ресурс]. - Режим доступа: http: // www.consultant.ru/ (дата обращения 20.10.2017).

4. Каримуллина А.Э. Правовые стимулы и правовые ограничения в гражданско-правовом регулировании обязательного страхования / А.Э. Каримуллина // Пробелы в российском законодательстве. — 2017. — № 2. - С. 107-109.

5. Конституция Российской Федерации (принята всенародным голосованием 12.12.1993) (с учетом поправок, внесенных Законами РФ о поправках к Конституции РФ от 30.12.2008 № 6-ФКЗ, от 30.12.2008 № 7-ФКЗ, от 05.02.2014 № 2-ФК3, от 21.07.2014 № 11-ФКЗ) / Правовой Сервер КонсультантПлюс [Электронный ресурс]. — Режим доступа: http://www.consultant.ru/ (дата обращения: 22.10.2017).

\title{
Боргояков Ф.В. \\ Судебная защита прав ребенка при незаконном использовании его персональных данных \\ Хакасский Государственный Университет им. Н. Ф. Катанова \\ (Россия, Абакан)
}

doi: 10.18411/lj-05-2021-166

Научный руководитель Никиташина Н.А.

\begin{abstract}
Аннотация
У большинства граждан уже успела сформироваться привычка к регулярному согласованию посредством своей подписи согласования на обработку своих персональных данных и персональных данных своих детей или несовершеннолетних граждан, законными представителями которых они являются при обращении в образовательные организации, медицинские учреждения, государственные органы и в иных ситуациях различных документов. При попытках незаконного использования персональных данных несовершеннолетних, лицом, способным оказать защиту и противостоять этому, в первую очередь, выступает законный представитель несовершеннолетнего. В ситуации, когда законному представителю не удается разрешить конфликт с правонарушителем напрямую, он может обратиться с иском о защите персональных данных в суд, выступая истцом самостоятельно, защищая права ребенка, которые были нарушены, либо истцом может выступать Роскомнадзор (Федеральная служба по надзору в сфере связи, информационных технологий и массовых коммуникаций), если правонарушение было совершено в области связи и СМИ, а законный представитель направил свое заявление в данную службу.

Ключевые слова: судебная защита, права ребенка, персональные данные, защита персональных данных, незаконное использование персональных данных.
\end{abstract}

\section{Abstract}

The majority of citizens have already formed the habit of regularly agreeing, through their signature, to the processing of their personal data and the personal data of their children or minors, whose legal representatives they are when applying to educational organizations, medical institutions, state bodies and in other situations. In the case of attempts to illegally 